\title{
THE LAST OF THE SOVIETS' HOME: URBAN DEMOLITION IN MOSCOW
}

\author{
Guénola Inizan (1) - Lydia Coudroy de Lille \\ Univ Lyon, Université Lumière Lyon 2, CNRS UMR 5600 EVS \\ UFR Temps et territoire \\ 5, avenue Pierre Mendès-France,F-69676 Bron cedex: France \\ e-mails: guenola.inizan@univ-lyon2.fr • lydia.coudroydelille@univ-lyon2.fr
}

\begin{abstract}
This paper is dedicated to a program of the demolition of thousands of housing estates built during the Khrushchev period in the Federation of Russia. Although this process has been undertaken since the beginning of the twenty-first century, it has seen a significant growth in 2017 within the program called Renovation. The paper begins with the historical and geographical context that led to the birth of this layer of the Soviet architecture and presents Renovation as it has been completed in 2018 in Moscow, as well as the reaction of the inhabitants of these blocks.
\end{abstract}

\section{Key words}

Russia $\bullet$ Moscow $\bullet$ demolition $・ K h r u s h c h e v k i \cdot$ Renovation $\bullet$ urban policy

Lidochka (watching at the room)

"Could it be possible that this apartment is ours?

Boris

Yes, ours. I mean, yours...Admire! An annex of your museum. A typical dwelling of the second half of the twentieth century. Early reinforced concrete period. Era of mass supply. Everything is genuine, please don't touch!"

Dmitri Shostakovich, Moscow, Cheryomushki, operetta, 1959.

Ed. Opéra de Lyon, 2004.
"They say about us: 'The communists used to live in palaces, they used to eat caviar with a spoon. They built communism for themselves.' God! I have shown you my palace: an ordinary two-rooms $57 \mathrm{~m}^{2}$ flat..."

Elena Yurevna S., third secretary of the regional Committee of the Party, in

Svetlana Alexievich, Secondhand times: The Last of the Soviets, translated from the French Edition, La fin de l'Homme rouge, Arles: Actes Sud, 2013: 69. 


\section{Introduction}

Moscow, Cheryomushki is an operetta composed in 1959 by Shostakovich in which one of the elements of the drama concerns the allocation of flats in a new housing estate, in the Cheryomuschki district in Moscow. Fifty-four years later, Svetlana Alexievich describes in her book Secondhand times: The Last of the Soviets how Russian citizens have been losing their landmarks since the fall of the USSR. One of the persons interviewed in this book defends the honor of the ex-communists. She proclaims that her tworoom flat is far from being a palace and emphasizes that it is only $57 \mathrm{~m}^{2}$. Both works discuss the same generation of houses of the Khrushchev time, which are the objects of this article. A major part of them are supposed to be demolished, and this program of demolition has already started. In February 2017, the mayor of Moscow Sergei Sobyanin announced that a huge program called Renovation would be set up during the next months. The aim is to get rid of the khrushchevki, apartment blocks recognizable for their five-story structure and often called khrushoby (from the Russian world trushoby, 'slums') because of their dilapidation and lack of amenities. In the framework of this urban policy, almost 5,000 buildings will be demolished, and one-tenth of the Muscovite population is likely to be rehoused. Demolition policy was already a widespread tool for managing the urban space under the previous mayor Luzhkov in the 1990s and the 2000s, but the ongoing Renovation program is unprecedented concerning the scale and the systematic aspect of the demolition. The Renovation program illustrates the way urban renewal is provided today in Russia. It also raises the question of spatial justice and the right to the city because it is facing resistance from the residents, although a process of consultation has been set up. The aim of the paper is to present the state of this urban project in Moscow, in the light of the place of demolition in the history of the Soviet and post-Soviet city and of the housing situation.

\section{Demolition in Central and Eastern European cities}

The demolition of housing estates in Soviet or post-Soviet cities has not been treated per se by the scientific literature, as it has not previously been carried out at this scale. Nevertheless, the way some cities or parts of cities in Central and Eastern Europe have been destroyed has been analyzed in several fields of research, in history, geography, or history of architecture. Of course, one part of the literature in history addresses the consequences of wars in the development of cities in the countries that were most concerned by warrelated destruction (Barjot et al. 1997), some of them noting that even in the Eastern bloc, the treatment of prewar legacies was more diverse than expected (Diefendorf 1989). Few of them analyze war-related destruction in the Soviet Union, which impacted 1700 cities and towns (Lowe 2013). In his book dedicated to "The destruction and renewal of the historic metropolis", Anthony M. Tung compares Moscow and Beijing in the same chapter (Tung 2001). In Poland, the destruction of cities by the Nazi regime was not a consequence of the war but an objective, aiming to destroy the identity of the nation. The capital city had to be rebuilt and resettled for the benefit of the Germans, as the Pabst Plan showed. Books and albums about the destruction due to the Second World War are plentiful (Ciborowski 1969; Jankowski 1990), and some destruction was a tool of propaganda at a time when "all the nation builds its capital city" (Bierut 1951).

More rarely, the literature notes the existence of Renovation policies in the Soviet Union as a result of the industrialization of the Soviet urban planning and housing construction: Kalinina explains that the construction organizations, with the incentive to increase their costs, were encouraged to demolish the old urban structure before erecting prefabricated high-rise blocks instead of restoring the old buildings (Kalinina 1992). Tung also points to the lack of maintenance of the housing stock in general, especially 
of the prerevolutionary houses. He emphasizes that destruction had begun in the interwar period in the Soviet Union and concerned "approximately 50\% of the historically significant buildings of Moscow" (Tung 2001: 155), in particular during the preparation of the 1935 master plan of Moscow. In Bucharest, the demolition of the old structures of the city to impose a new socialist urbanism reached a peak under the regime of Nicolae Ceaușescu. In an area of 400 hectares, 9,000 houses were destroyed between 1984 and 1987 to build the People's Palace (losa 2006).

As far as the recent period of urban development is concerned in post-socialist Europe, the destruction of urban objects has been analyzed in the light of the removal and very often the destruction of symbolic objects in the urban landscape, such as statues of Lenin, Stalin and others. This 'symbolic policy', aiming for the decommunization of the landscape, was sometimes driven by national and local authorities and sometimes more spontaneous and aimed for a radical transformation of the visual identity of public spaces (Krakovsky 2005; Czepczyński 2010; VoisinBormuth 2013). In Moscow, the dismantling of Dzerzhinsky's statute in Lubyanka square has been analyzed by Alexander Etkind as a way to build a 'new order' (Deschepper 2017). The eradication of these monuments and the building of new urban objects in a disjointed fashion created an urban landscape that has often been described by scholars with the term 'chaos' (Cieśla 2000; Leśniakowska 2009; Kusiak 2014). In other cases, some objects were more discreetly forgotten, marginalized, redefined, and sometimes partially or discreetly destroyed because of the pressures of the real estate market. This has been analyzed as a cycle associating stages of disregard, 'banalization', and sometimes demolition (Coudroy de Lille \& Guest 2010; Coudroy de Lille 2011). This is why in recent years, the critical issue of the patrimonialization of the Soviet or socialist architecture has been addressed. What should be restored or saved in the post -socialist or post-Soviet context? This issue is closely related to the democratization and the territorialization of societies because the heritage and the urban landscape are parts of the collective memory on a national (Ter Minassian 2013) or on a local scale (Carton de Grammont 2009).

The program of demolition of the housing stock of the Khrushchev times in Moscow and the struggle for its preservation will be analyzed from this last perspective, as a political, and not only an architectural issue.

\section{Methodology and sources}

To do so, we will analyze first the historical and geographical context that led to the construction of this layer of the Soviet city, developing two sub-questions: in which context of urban growth did these housing blocks appear in the history of the Soviet Union, and which conceptions of housing led to this model of architecture? Second, in a context of the metropolization of Moscow, what are the characteristics of the housing situation in the Russian capital city that could explain this choice of urban renewal? The program Renovation will be at the core of the second part of the paper, and its spatial, political and social aspects will be presented: how and why has it been launched by the municipality, and how do residents react? The paper relies on a survey of the literature, on desk analysis as far as urban growth and housing conditions are concerned, and on other sources such as legislative texts, the local press and social networks. These sources were completed by the empirical collection of data. Free data has been used to analyze the results of the consultation that inhabitants took part to after the announcement. It has been used for mapping the project itself in Moscow, and its reception by inhabitants. This quantitative reading of inhabitant's reactions has been completed by observations and interviews with inhabitants and militants provided in May-June 2017 and March-April 2018 in Moscow. Eleven inhabitants and activists have been interviewed during the second research field. 


\section{The khrushchevki in their historical and spatial context}

\section{Towards the industrialization of housing in the Soviet Union}

The Bolshevik revolution was unexpectedly born in a country with few large cities and a very low urbanization rate. According to long-term surveys about the population of cities in Europe, the urbanization rate of Russia (in its European part) was stable, at approximately 5\%, from 1300 to 1800 (Bairoch et al. 1988) and had reached 18\% just before the Revolution. However, one of the major consequences of the Bolshevik Revolution and of the history of the Union of Socialist Soviet Republic (USSR) is the huge increase of the urbanization rate, driven by the industrialization of the country. Studies about the rhythm of urbanization in the Soviet Union show that the maximum level of urban growth did not appear at the very beginning of the Revolution, which was a time of trouble for cities due to World War I and the Civil War, but a few years later, with the beginning of the industrialization during the Five-Year Plan. Between 1926 and 1939, the urbanization rate grew from 18 to $33 \%$, that is, by $6.5 \%$ per year, much more rapidly than the rates in the United States or Europe, for which the same growth of the urbanization rate took respectively three to ten decades (Harris 1970). Since the mid-1950s, half of the population of the Federation of Russia has been living in cities (Fig. 1).

Although the percentage of urbanization has been stabilized at approximately $74 \%$ since the nineties, the absolute number of the urban population has been decreasing, from 109 million in 1995 to 105 million inhabitants in 2015, in a context of global demographic decline in Russia. The process of urbanization in the Soviet Union and more precisely in Russia is thus definitely a major legacy of the Soviet regime. Together with the city growth, contrasting options for the housing of the Soviet citizens were discussed and achieved, which led to the building of the khrushcherki.

As we know, the Marxist ideological background is quite light as far as spatial development is concerned. It outlines the elimination of inequalities between rural and urban

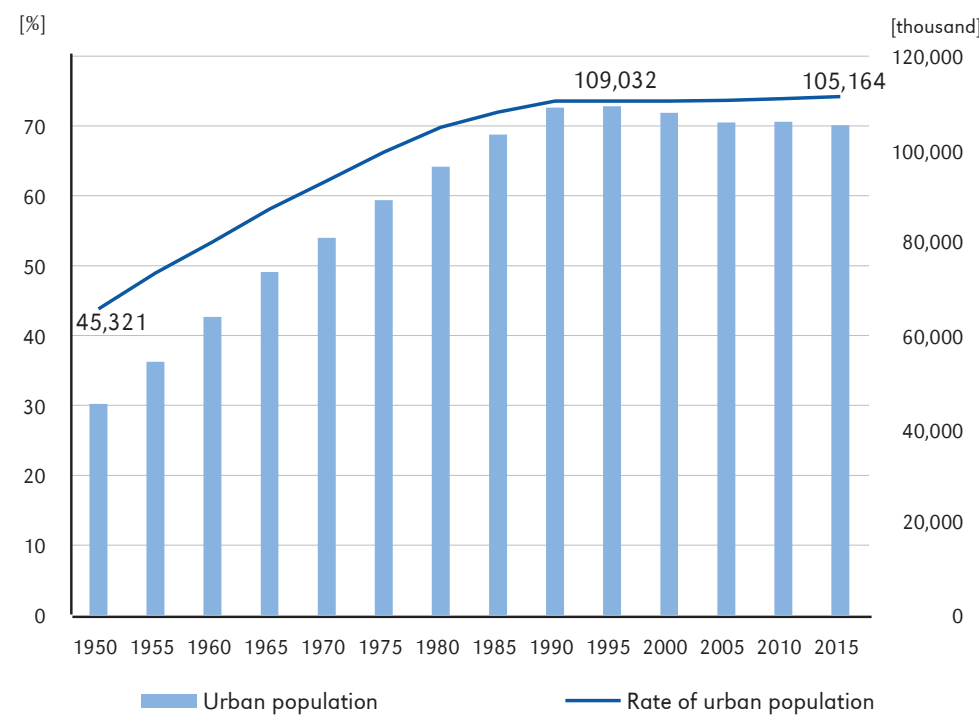

Figure 1. Urban population in the Russian Federation (1950-2015). Coudroy, UMR EVS 2017

Source: United Nations, Department of Economic and Social Affairs, Population Division (2014). World Urbanization Prospects: The 2014 Revision, custom data acquired via website. 
spaces and of private property, beginning with the existing housing stock. The problem of housing shortage and overcrowding in urban dwellings should be resolved automatically through the proletarian revolution (Engels 1976 [1873]). However, many divergent positions about the nature of the city and its role in the social transformation in the Revolution appeared at the beginning of the Soviet Union. Therefore, city development and thereby housing in the Soviet Union took various forms, according to a succession of radically opposed architectural turns, which are indeed political and ideological. During the twenties, much emphasis was put on theoretical models of housing targeting the socialist transformation of the way of life: according to the constructivist architects, a house was one of the possible 'social condensers', together with industrial, social and cultural buildings. The 'social condensers' according to these avant-garde architects, such as Moises Guinzburg, were urban objects that were supposed to transform the entire society through their form and the way they should be used. Thus, they were considered as tools to realize the socialist transformation of the family, of work, and of education (Kopp 1975). Many ambitious projects were proposed in this decade full of highly ambitious theoretical and aesthetical debates about arts, architecture and housing. Some of them were also achieved, such as the House-Commune Narkomfin in 1929, but the rhythm of dwelling construction was low during this period. Hence, the housing issue was treated mainly by requisitions of the existing stock of flats. They had begun already in 1917, especially in Moscow, and were pursued in 1921 with the ambitious operation of "material redistribution of living surface", which led to the famous komunalki, i.e., 'communal apartments' (Azarova 2007b). Beginning in 1929, Stalin begun to dismantle the housing system that had begun to be set up in the previous decade. The private sector in housing construction was eliminated, and the housing cooperatives were first subordinated to industry and then abolished in 1937.
The modern conceptions of the constructivist architecture were rejected for the benefit of the monumental and neo-classic aesthetic of the socialist realism (Kopp 1985). After Stalin's death, criticism against socialist realism was expressed in the Resolution of the Central Committee and Council of Ministers named "On the removal of exaggerations in planning and building", signed by Khrushchev and Bulganin on 4 November 1955 (Aman 1992). This sharp turn launched a new phase of urbanization and housing conception, the destalinization of architecture: "Soviet architecture must be characterized by simplicity, austerity of form, and economy of layout. Buildings must be given an attractive appearance, not through the use of contrived, expensive decorative ornamentation, but by an organic connection between the architectural form of building and its purpose" (Khrushchev \& Bulganine 1955, quoted in Aman 1992: 219). As Aman argues, this declaration "closes the gap between the East and the West in architecture" because of the convergent technological choices for the industrialized building, the modern forms, and the adoption of zoning in urban planning. The industrialization of housing construction was supposed to remedy the housing shortage and provide to each household an independent dwelling in the future in the Soviet Union.

There are different stages of construction of 'industrial housing building' (industrial'noe domostroenie). The first wave began in 1957, when the housing decree aiming to find a solution to the urban shortage was adopted. On the national scale, the effects of industrialization on housing construction were immediate: the construction of dwellings tripled between 1950 and 1960, from 20 million $\mathrm{m}^{2}$ of overall living space to 59 million $^{1}$ (Andrusz 1984). This significantly reshaped the landscapes and the social organization of cities: seventy-five million people moved into these new houses

\footnotetext{
${ }^{1}$ Soviet statistics provide data about housing construction in million $\mathrm{m}^{2}$ of living space.
} 
in the whole USSR between 1957 and 1963 (Attwood 2010). These housing estates were designed on the model of the micro-rayon and thus offered social, cultural and commercial amenities, as well as a green environment between the blocks. In Moscow, in less than ten years, the new surface of living area more than doubled, from 0.8 million $\mathrm{km}^{2}$ in 1949 to $1.8 \mathrm{~km}^{2}$ in 1959. The 'Khrushchevki peak', as it is called in the decree "Programme of Renovation of the housing stock" of 1 August 2017, was reached in 1963-1964, when 2.5 million km² of housing were built (Decree N-497 2017). Four other waves of industrial housing construction succeeded each other from the beginning of the 1970s to the beginning of the 1990s. The newly built housings were broadly improved in terms of amenities and comfort between these stages. The industrialization of housing production never ended in the Soviet Union: in 1989, almost 89\% of new urban construction was still made of frame-and-panel apartment buildings, and $70 \%$ of housing on the national scale was financed by state-owned enterprises and organizations (Kalinina 1992). However, during the Brezhnev period, the flow of newly built dwellings stagnated at a level between 66 and 76 million $\mathrm{m}^{2}$ per year, although the population was growing. This is why the situation of shortage continued. The poor conditions of housing at the end of the Soviet period can be summarized in a few figures: in 1989, 14.3 million families were on housing waiting lists $(23 \%$ of the urban population), approximately 15 million people lived in communal apartments, and 12 million lived in hostels (Kalinina 1992). However, the communal apartments were highly concentrated in major Russian cities, where up to $60-80 \%$ of the population was still living in such flats at the beginning of the nineties (Azarova 2007a). Thirty-six percent of the households (representing 14\% of the total population) used to have a living space less than $9 \mathrm{~m}^{2}$ (Kalinina 1992: 251).

\section{Housing conditions in Russia and in Moscow today}

After the collapse of the USSR, the economy of housing shifted to a market-oriented model similar to that in other countries of Eastern Europe. Privatization of the existing stock was launched first in 1988 under Mikhail Gorbachev's presidency, for tenants wishing to buy their own flat only. It was enlarged in July 1991 with the Law on Privatized Housing in the Russian Soviet Federative Socialist Republic RSFSR. In Moscow, flats were given to their occupants free of charge, and the privatization process ran faster than elsewhere in Russia. After one decade of dismantling of the existing model of the housing economy, the level of housing construction in the Russian Federation dropped to only 30 million $\mathrm{m}^{2}$ in 2000, and it reached 80 million in 2016 . The available total floorspace per capita is now $24.4 \mathrm{~m}^{2}$ in the country, Moscow being the Russian city where this average is the lowest at $19.7 \mathrm{~m}^{2}$ per capita (Decree N-497 2017). In comparison, in Poland, which is known for suffering the worst shortage of housing among the Central European countries, for the same year 2016, the average floorspace per capita was $26.8 \mathrm{~m}^{2}$ in cities.

The Russian Federation has lost 3 million inhabitants since the end of the Soviet regime, with the population falling from 147 million in 1990 to 144 million in $2017^{2}$. This general context of decline also impacts cities: the majority of Russian cities (70\% of them) have been undergoing a demographic decline since 1990 (Cottineau 2012). However, this trend is unequally shared by cities, for the country has been undergoing a strong metropolization process (Kolossov et al. 2002). Thus, big cities, and especially Moscow and Saint Petersburg, have been experiencing very significant integration into the global economic flows (Hamilton et al. 2005) and have seen concentrating incomes and demographic growth (Fig. 2).

\footnotetext{
2 According to UN data.
} 


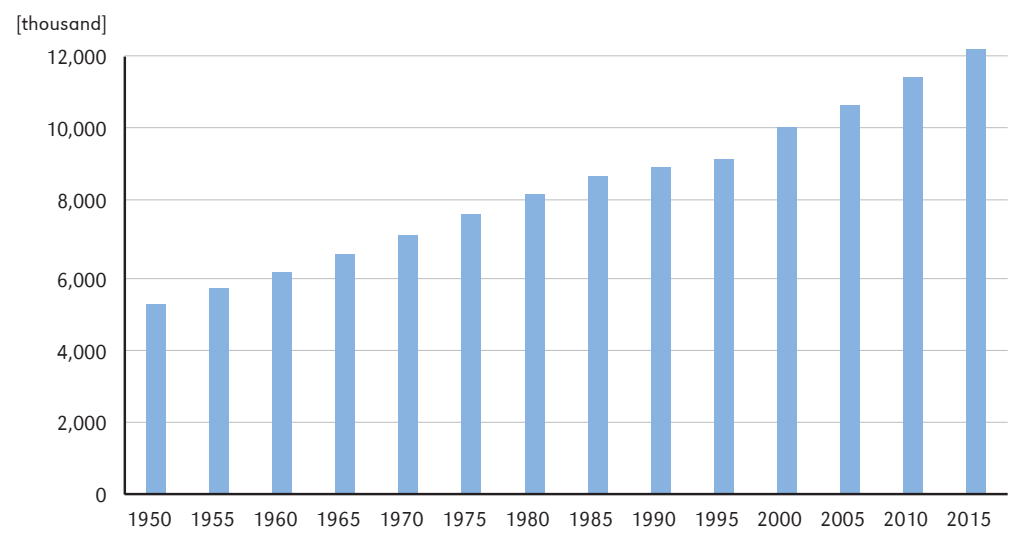

Figure 2. The population of Moscow. Coudroy, UMR EVS, 2017

Source: United Nations, Department of Economic and Social Affairs, Population Division (2014). World Urbanization Prospects: The 2014 Revision, custom data acquired via website.

The demography of Moscow is still growing, and the real estate market is very dynamic. The 'exceptionalism' of the city is based on its location in the heartland of Russia at the crossroad of economic flows, its status of capital city, and the polarization of the high-income population (Medvedkov \& Medvedkov 2007). Thus, the demand for housing surface in the city core has been significantly growing since the nineties, and the housing market is polarized by a sustained supply and demand for upscale housing, for sale or rent. The privatization process of the existing housing stock could not meet all the demand for luxury housing: in the city core, certain old residential quarters were torn down to make room for exclusive condominiums and have been undergoing a very sharp process of gentrification (Golubchikov \& Badyina 2005). This could be the time now for the Khrushchev housing districts, which enjoy a subcentral location, connections to the metro network, and a pleasant environment sixty years after trees were planted. In the beginning of the twenty-first century, the mayor Yuri Luzhkov already projected a ring of sixty high-rise blocks in a neo-Stalinian style precisely in these areas (Amestoy 2004).

\section{The Renovation program}

In February 2017, the mayor of Moscow, Sergei Sobyanin, announced that a huge program called Renovation (renovatsiya) would be set up in the following years. More than five thousand housing buildings, officially designated for their dilapidation and lack of amenities, are to be demolished, and onetenth of the Muscovite population is likely to be rehoused up to 2032. This program will imply a restructuration of the architecture and the landscape of the city as well as sociospatial reconfigurations linked to the rehousing of the inhabitants. It is too early to predict the socio-spatial consequences of the program, whose many stages are still to define. However, the announcement and the first part of its implementation already reveal that demolition is a governing tool that raises new political and social stakes.

\section{Making room for the capitalist city}

As Oleg Golubchikov explains in an article arguing for the interconnection between cities and socio-economic changes, "cities do not simply exist within transition; they are part of transition" (2017: 270). Both destroying the physical heritage of the past and 
liberating space to build a new order, demolition constituted, and still does, a major part of this 'transition'. In Moscow, demolition revealed and participated in the building of the 'capitalist mega-city' (Kolossov \& O'Loughlin 2004). This 'creative destruction' (Argenbright 2016) was organized mainly by the city government. According to Robert Argenbright, as it has resisted the Kremlin's pressure to privatize land and still has too much power over the land, this local government cannot be qualified as 'neoliberal'. The destruction of housing buildings is probably the most striking part of this new phenomenon. Oleg Golubchikov and Anna Badyina, in a study devoted to the Ostozhenka area, showed how demolitions in central Moscow, notably of the prerevolutionary period buildings, were supported by the city government, which had financial interests in the demolitions, taking benefit from the income of the new constructions ${ }^{3}$. For developers, demolishing was three times less expensive than restoring, and more often, only the façade of the old buildings was kept. These demolitions-reconstructions implied the progressive disappearance of working classes in this central area, which used to be characterized under the Soviet Union at the beginning of the 1990s by a social mix (Badyina \& Golubchikov 2005). Meanwhile, the building sector was one of the most profitable in the Russian capital, and a handful of urban developers made a fortune, such as the wife of the mayor Yuri Luzhkov, Elena Baturina.

After Luzhkov (1992-2010) was dismissed, Sergei Sobyanin took up office, which marked a turning point in urban policies. In addition to general reorganization of the administrative structure ('New Moscow' in 2011) and the settling of new infrastructures (such

3 "Since the post-default market stabilization, the investment contracts for house building in central Moscow require investors to transfer as much as $50 \%$ of the construction-ready output to the city. If previously developers were able to compensate the city 'in kind' with equivalent building space or social infrastructure elsewhere in Moscow, more recently the city has demanded only cash for the market value of its share" (Badyina \& Golubchikov 2005: 121) as the second metro circle MTsK, opened in 2017), which were more or less a continuity of previous projects, the city government supported different programs to reshape public spaces, especially in the center. Many programs aimed to refurbish parks and streets, to create "a pleasant urban environment" and to "make Moscow a city pleasant to live $\mathrm{in}^{\prime \prime}$. To "clear the ground", to use Boren, Kalyukin and Byerley's expression in a study devoted to the Renovation of the central and famous Gorky Park (Kalyukin et al. 2015), many shops were removed and demolished from the public space. Another example is the demolition of approximately one hundred shops and kiosks surrounding central metro stations, many of them demolished on the night of 9 February 2016 (Perry 2016). This changed the habits of Muscovites who used to buy drinks or fruits when going out of the metro and created empty squares, supposedly to epitomize and participate in the shaping of a clean and modern city., Kalyukin, Borén and Byerley see in these changes the "second generation of post-socialist change" (Kalyukin et al. 2015) in which capitalist dynamics might be less visible than under the previous period of commercialization and privatization of public spaces, but more pervasive.

\section{Governing the demolition}

This context highlights and puts under question the demolition of the khrushchevki. These housing buildings are not a new target of the city government. As early as 1995, several decrees were signed by the municipality government to organize their demolition up to 2010. Since the declaration of these decrees, gradually organizing the demolitions of the first generation of khrushchevki (Decree N-497 2017), more than 1700 houses have been destroyed, and currently, the plan has been nearly completed ${ }^{5}$. The current

\footnotetext{
${ }^{4}$ As it is written in the site of the municipality concerning the 'my street' (moya ulitsa) program - https:// www.mos.ru/city/projects/mystreet/ [20 March 2018].

5 When the 1 August 2017 decree was published, 1722 houses had been destroyed, and there were
} 
program has the same official aims: to get rid of dilapidated houses, to provide inhabitants with comfortable flats and to "give a modern image of the capital of the Russian Federation", as it is expressed in the decree of 1 August 2017. This document also highlights the necessity to deal with the densification of the city in the context of the urban growth and the small height of many buildings aforementioned ${ }^{6}$. However, a short time after the announcement of the program by the mayor in February 2017, it became clear that the demolitions of the khruschhevki planned under Luzhkov were not only to be imitated but amplified and undertaken differently. What is new is, first, the huge extent of this urban policy. In the first list posted on the site of the municipality of Moscow, more than 5,000 houses were included in the program, and $10 \%$ of the Muscovite population would be about to move; that is, three times more people were involved in this program than in the previous program, in five fewer years. The buildings on the list for Renovation cover the whole city, even if the southeast and some districts of the western part of the city are particularly concerned (Fig. 3). Much communication has been made by the government, and the majority of the Muscovites are aware that a Renovation is going on, although they often do not know exactly in what it will consist.

Indeed, behind the official aims, there are many unknowns concerning the setting up of the program. The numerous gray areas of its implementation seem to be its other prominent characteristic, notably concerning the criteria of inclusion of the houses on the list of demolitions. The massive demolition is justified by the technical state of the khrushchevki and the comfort of the citizens. In a decree organizing the conditions of the vote of the inhabitants (Decree N-245

51 left, which were about to be demolished. The program was $97 \%$ completed.

6 In the decree of the 1st August 2017, the average available surface per person in Moscow $\left(19.7 \mathrm{~m}^{2}\right)$ is compared to the one in other cities like New-York $\left(41.8 \mathrm{~m}^{2}\right)$, London $\left(31.5 \mathrm{~m}^{2}\right)$ and Tokyo $\left(25.9 \mathrm{~m}^{2}\right)$.
2017) 7 , the reasons why some buildings are on the list are made explicit: "general technical state of the buildings", "former admission into institutions of the public government, or institutions of the local governments due to plaints or proposals of the inhabitants, linked to the technical state of these multiapartment houses" or "results of a telephone survey carried out by the Moscow government". Nevertheless, some inhabitants' accounts and observations reveal that many houses included in the program do not match these criteria. Some of the houses built in the 1950 s or the 1960s are in very good condition and comfortable, notably when they have brick walls. Inside the houses, the condition of the flats varies, but some of them have been totally renovated by the inhabitants, and sometimes very recently. Some buildings included in the list of demolitions are not even khrushchevki. The association of the protection of architectural heritage Arkhnadzor published a list of approximately 200 buildings, notably from the constructivist period, an initiative that has brought up the withdrawal of these buildings from the list of demolitions (Mishina 2017). The calendar of the implementation is also unclear. The decree of 1 August 2017 specifies that the program should be realized up to 2032. On the site of the city government, the first places where inhabitants should be rehoused from 2018 to 2021 are mapped. However, most inhabitants have no idea when their house will be demolished and how it will happen: "it will be next month or in ten years", says an inhabitant from the Fili-Davydnovo district ${ }^{8}$, who bought her flat twelve years ago and does not want to leave.

\footnotetext{
7 Decree of the Government of Moscow N-245-PP of 2 May 2017 concerning taking into account the opinions of the population on the renovation projects of the housing fund in the city of Moscow. No details about the proceedings of the telephone surveys are given in this text, https://www.mos.ru/upload/documents/ docs/245-PP-sait.pdf [1 March 2018].

8 Interview in an inhabitant's home in March 2018.
} 
3A. Planned demolitions before the consultation of inhabitants (March 2017)

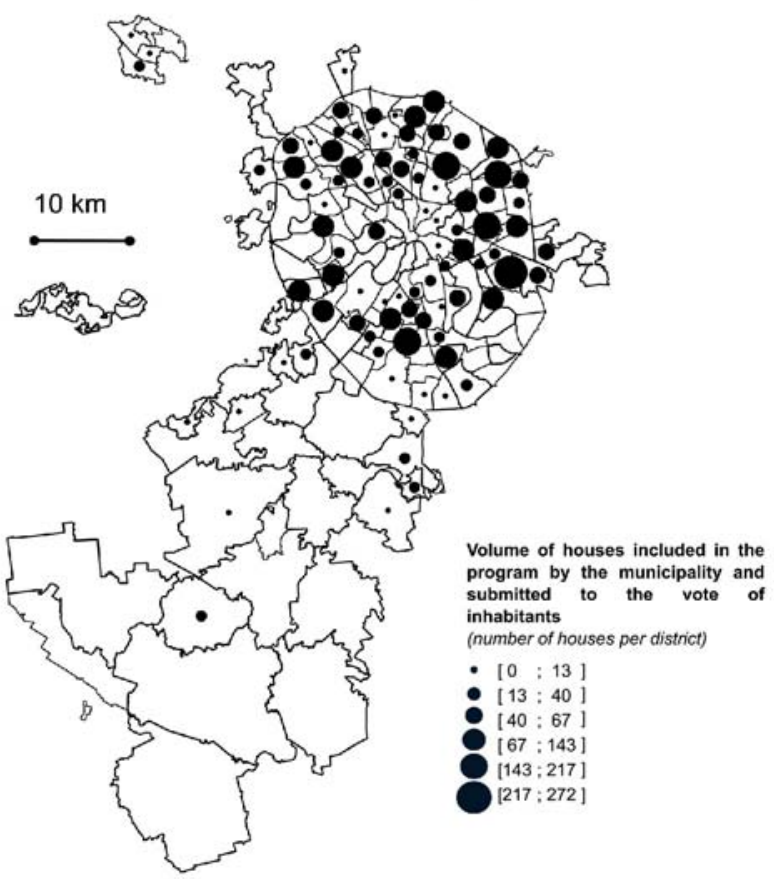

3B. Results of the consultation of inhabitants about the demolition of their houses (May 2017)

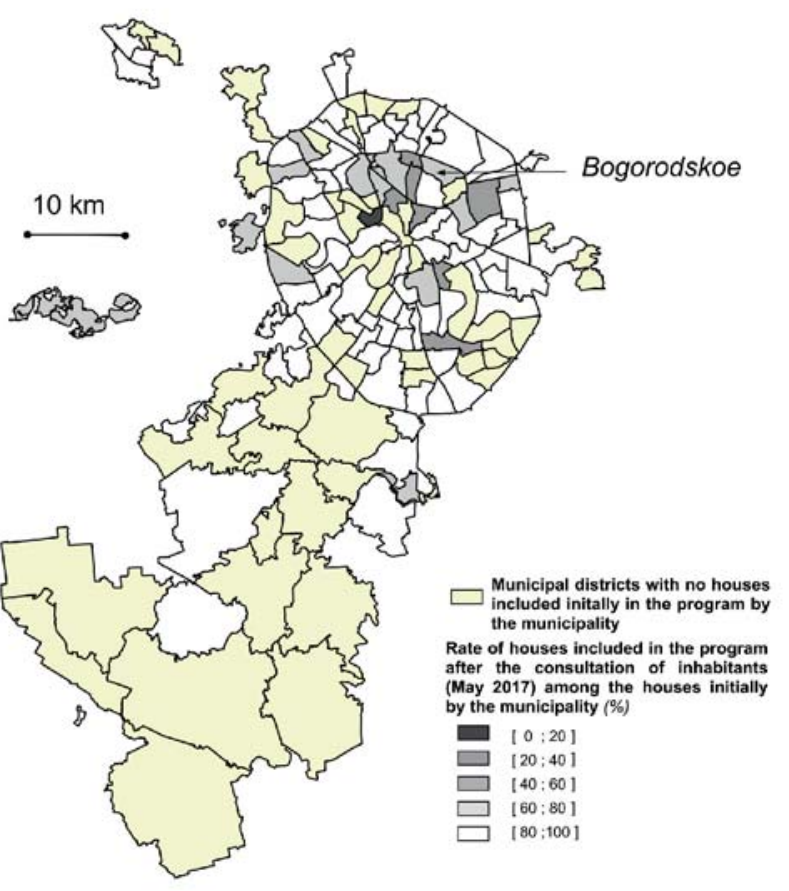


3C. Planned demolitions after the consultation of inhabitants (May 2017)

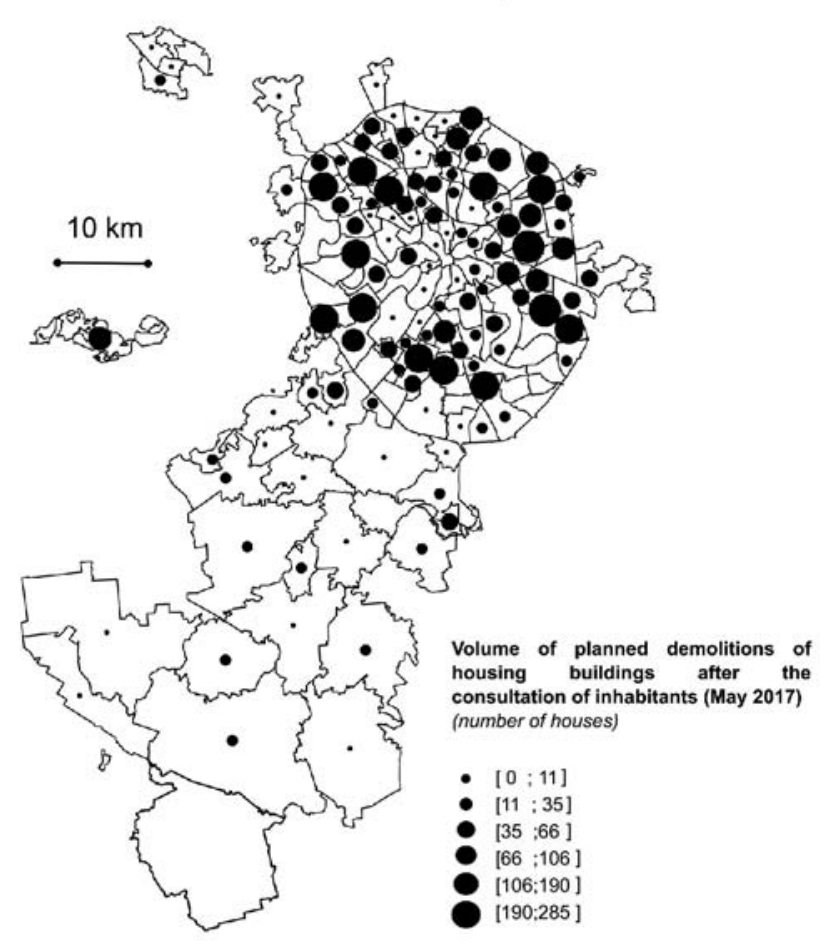

3D. Planned demolitions resulting from general meetings of owners (May 2017)

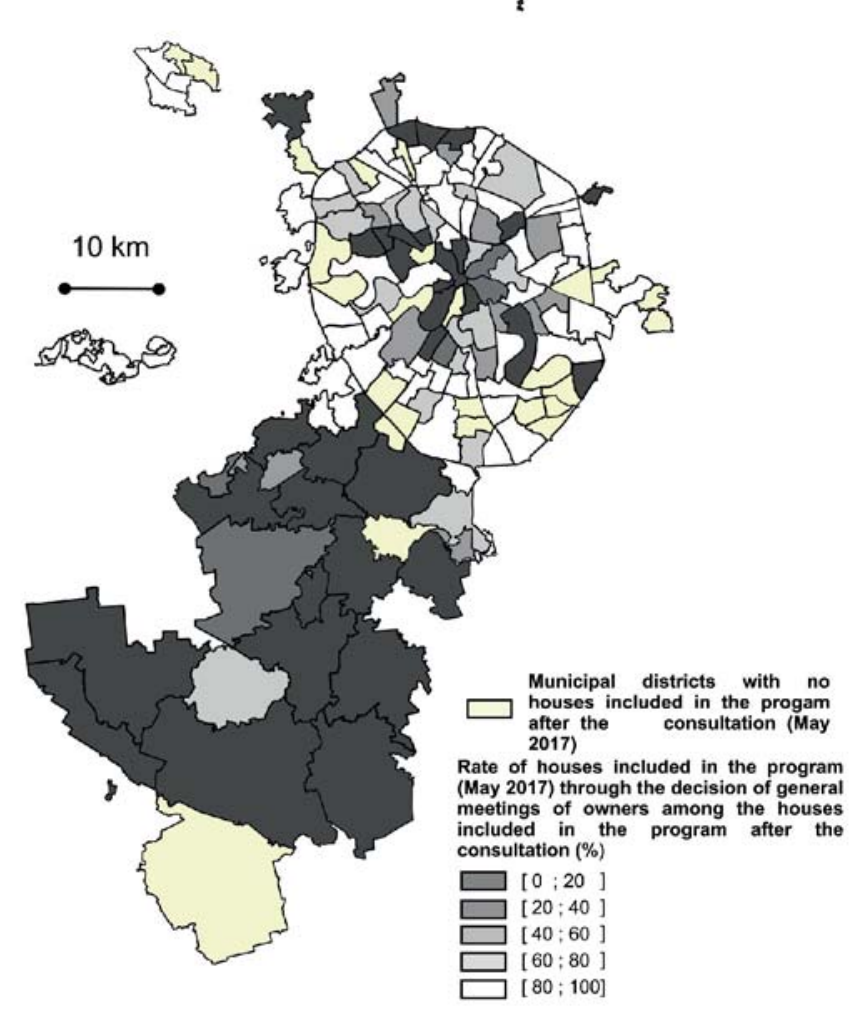

Figure 3. Planned demolitions in March and May 2017. Inizan, UMR EVS, 2018 


\section{Inhabitants and citizens in motion}

The demolition is an urban policy and a political tool used to deal with demographic evolutions and reshape the city to adapt it to 'modernity'. But it also provides an opportunity to lay the foundations for new relationships between the local authorities and the inhabitants.

In a decree (postanovlenie) of 2 March 2017 called "about the consideration of inhabitants' opinions in the program Renovation", it is explained that every owner or tenant of social housings can vote in favor of or against the demolition of their house. In line with some of Sobyanin's initiatives ${ }^{9}$, citizens are called to give their opinion on this urban policy, which contrasts with the previous waves of renovation in the Russian capital city. The consultation democratizes the process of demolition, but only as a posteriori consultation in a frame of an urban policy which is undoubtedly top-down. Whereas the calendar of demolitions is still not totally defined, the time for inhabitants to express their agreement or disagreement was quite limited. Once inhabitants learned that their house was likely to be demolished by a list published on 1 March 2017, they had one month to vote, between 15 May and 15 June 2017. The privileged way - as expressed in this decree - was on the mobile application aktivnyi grazhdanin (active citizen). It was also possible to go vote in a municipal center and vote twice, in which case the vote at the center would be the one that would be taken into consideration. The house would be demolished if two thirds of the inhabitants voted in favor of the demolition. The owners and inhabitants could also gather and decide the fate of their home together in the frame of general meetings of owners (obshchoe sobranie sobstvennikov) ${ }^{10}$, during or after

\footnotetext{
${ }^{9}$ Like 'active citizen' aktivnyi grazhdanin is a digital portal created in 2014 through which Muscovite can give their opinion on the development of their city.

10 Helene Richard's thesis is partly devoted to the use of this legal structure to manage the common areas in the frame of the emerging 'co-property' defined
}

the voting. When some citizens actively participated to the process, some inhabitants explained that the conditions of the vote were quite blurred and inefficient. According to some accounts, "it was only informal lists", "people could cheat" and "some neighbours didn't even realize that they were concerned"11.

For these reasons, the results of this voting have to be interpreted with caution. Moreover, since the inhabitants can exclude their house from the program if they meet in general meetings of owners, these results could have changed. They are yet the only element specifying the way the houses were included on the list of demolitions after the consultation of the inhabitants. We have been analyzing free date provided by the municipality: the list of the houses whose inhabitants have been called to vote (4,546 housing buildings), the list published after the consultation of the inhabitants (5,177 housing buildings) and the results of the consultation ${ }^{12}$. This led us to draw some conclusions from the consultation of the inhabitants.

First, on the city scale, the results show that the demolition was supported by the majority of the inhabitants who took part in the consultation (i.e. who voted or met in general meetings of owners). $88.9 \%$ of the houses of the first list were finally included in the list of demolition, that is to say inhabitants gave

in the new Housing Code (2005). She analyzed how inhabitants use the 'co-property' through the analysis of "legal offenses, controversies around the interpretation of the legislation, and layperson appropriation of the law" (Richard 2014: 625).

11 Interview in an inhabitant's home in March 2018. These opinions shared through interviewed are not numerous enough to draw any general conclusion, but they at least reveal that a part of the inhabitants feel they are put aside from the implementation of the demolition policy organized by the municipality.

12 These three sources are available on the site of the municipality of Moscow: List of the houses whose inhabitants consulted the vote https://www.mos.ru/Renovation_vote.pdf [1 March 2018], List of houses covered by renovation programme - https://www.mos.ru/ Renovation.pdf [1 March 2018], Results of the consultation per house: https://www.mos.ru/otvet-stroitelstvo/ itogi-golosovaniya-zhitelej-po-proektu-programmy-renovacii/ [1 March 2018]. 
their agreement ${ }^{13}$. The rate of opposition to the demolition varies depending on the area, as it can be seen on the map made out of these results (Fig. 3B). In the peripheral districts, notably those of the New Moscow (the south-east part of the city which was included to the municipality in 2011 and represents about the half of its whole surface) and those bordering the frontiers of the previous administrative limits, the inhabitants largely supported the program by voting in favor of the demolition. On the contrary, the rate of houses included in the program after the consultation is less important in the central areas. Many studies about Moscow, concerning the program Renovation, underline the lack of data to analyze social dynamics in the urban space (Gunko et al. 2018). Nevertheless, research also reveals that the center and the peripheral areas are differentiated by the socio-economic status of their inhabitants, the center being more flourishing (Vendina 2014). This leads to the hypothesis that the opposition is positively correlated to the socio-economic level of their inhabitants. This correlation should be verified through further quantitative works and on a broader scale in order to avoid an ecological fallacy. Moreover, the results of the consultation in some districts do not fit to the general socio-economic structure of the city described in these works. In some districts of the east part of the city, the level of opposition to the demolition is remarkable, whereas the eastern part is less flourishing than the western one (Vendina 2014).

In order to strengthen this hypothesis, we focused on the results of the consultation on the district scale and on the Bogorodskoe district, situated in this south-east part of the city (Fig. 3B) because many houses were included in the program and the part of houses excluded from the program by its inhabitants is one of the most important of the

\footnotetext{
13 The rate of participation on the city scale is not indicated but the site presents the result for each flat per house. In general, it is indicated that dozens of flats per house participated to the vote.
}

city. Among the free data of the municipality, we chose the type of walls because most of the interviewed people criticized the program for including indifferently brick-walled and concrete-walled houses. The analysis of the results of the consultation shows the material typology of blocks is largely correlated to the vote. Only 51\% of the brick-walled houses were included in the program after the consultation (45 out of 89 ), whereas $92 \%$ (87 out of 95) of the concrete-walled houses inhabitants voted for the demolition of their concrete-walled housings. The brick-walled houses (notably the $1-511$ mode ${ }^{14}$ ) are usually associated to better construction properties, like thermal insulation or soundproofing. They are more expensive and more often privatized (Richard 2008) than houses with concrete walls. This result tends to reinforce the hypothesis that the opposition to the program is not only correlated to social and economic capitals, but also to the architectural properties of blocks.

Among the houses themselves, reactions of inhabitants may be very different. Although the accounting of the vote rounds the voting up, the rate of inhabitants who voted in favor of the program per house is rarely $100 \%$ and never $0 \%$. Two interviewed inhabitants opposed to the demolition of their house criticized their 'pro-renovation' neighbors for being ignorant or indifferent to their home. Reactions to the demolition thus reveal different appropriations of their apartments in the same house and contrasted perceptions among inhabitants. The widespread image of khrushchevki as a homogenous soviet urban stratum is smashed.

The analyses of the results consultation point to another conclusion: the importance of the meetings of owners. On the city scale $21.2 \%$ of the houses have been included in the list of demolition as a consequence of the decision of general meetings of owners. The map illustrating this result on the

\footnotetext{
14 Series of industrial houses built mainly between 1959 and 1968, with 4 storeys and brick walls. Source: tipadoma.ru [1 March 2018].
} 
district scale (Fig. 3D) shows that is was particularly used in some central areas but also in the New Moscow and in districts initially not included in the program. This first result of the consultation shows that these committees were both a tool and scale of decision.

In parallel with this top-down designed participation, some citizens' movements reveal that a new form of urban social movement is emerging against demolitions. Many studies have explored the social and political movements in post-Soviet Russia. They have showed that these movements are very important for understanding Russian society and politics, which cannot be understood by focusing strictly on the political life (Daucé 2005). Some studies specifically analyze urban contexts, notably to show that the occupation of the urban space is a political stake (Abramova 2015). When the conservation of the space is the aim of the mobilizations, the stake is often the 'heritage' from an architectural point of view. "Heritage contestations" had indeed "laid the groundwork" (Argenbright 2016) at the end of the USSR for other forms of contestation. Some ecologist movements and protests against the 'infills' (tochechnaya zastroika) also participated recently to constitute an overall framework of urban mobilizations that the program Renovation has stirred up. Being directly concerned because they do not want to leave their house or protesting against "the way all the program is realized"15, some people went to demonstrations and took part in collective action for the first time. Some common targets and justifications seem to characterize an emerging speech. The attachment to their houses and the right to choose the place to live is the most widespread claim. The opposition to the transformation of the urban landscape and of the living conditions are also highly criticized: the inhabitants do not want to be rehoused in the 'ghetto' (Fig. 4); they are fighting

\footnotetext{
15 Interview with a participant of anti-demolition meetings in March 2018 in Moscow.
}

against 'deportation'16 and criticize the city government's tendency to take the 'golden ground' next to the city center, where lowstory buildings will be replaced by high towers. In May and June 2017, several demonstrations gathered hundreds of inhabitants in the center of Moscow with the same motto "against demolitions" ${ }^{17}$. Structures referring to a common identity and promoting the attachment to piatietajki such as the Facebook group "Muscovite against demolition" (Moskvichi protiv snosa), the magazine "The indestructible Muscovites" (Nesnosnye Moskvichi18) or the "For Muscovites' right"19 meeting, constitute temporary or permanent forms of public spaces where these contesting ideas are shared. Some of the militants even entered the political sphere by running in the elections of the municipal deputies of the districts in September 2017 and have been elected.

However, in the same house, the variety of the flats can be an obstacle to the expression of shared opinions and a fortiori of a common protest or support to the program. This can imply the inexistence of local alliances that characterize grassroots movements and even arguments between neighbors. Some inhabitants explained that they are against the demolition because they bought their flat and renovated it but that some people living in shared flats (komunalki) in the same house or in dilapidated flats are in favor of the program. In particular, some dilapidated buildings with a particular architectural have been included in the program although they were not khrushchevki because their inhabitants wanted to leave, to which associations for the protection of architectural heritage protested. Thus, in the Krasnoselskii

16 The guarantees later announced by the municipality about the rehoused inhabitants (they should be rehoused in the same district) partly smashed these critics.

17 For example, 14 May around the metro station Tchistye Prudi and 12 June on the Sakharov Boulevard.

18 The title is a pun: nesnosnye means both 'unbearable' but also 'indestructible'.

19 On 27 May, square Suvorovskaya. 

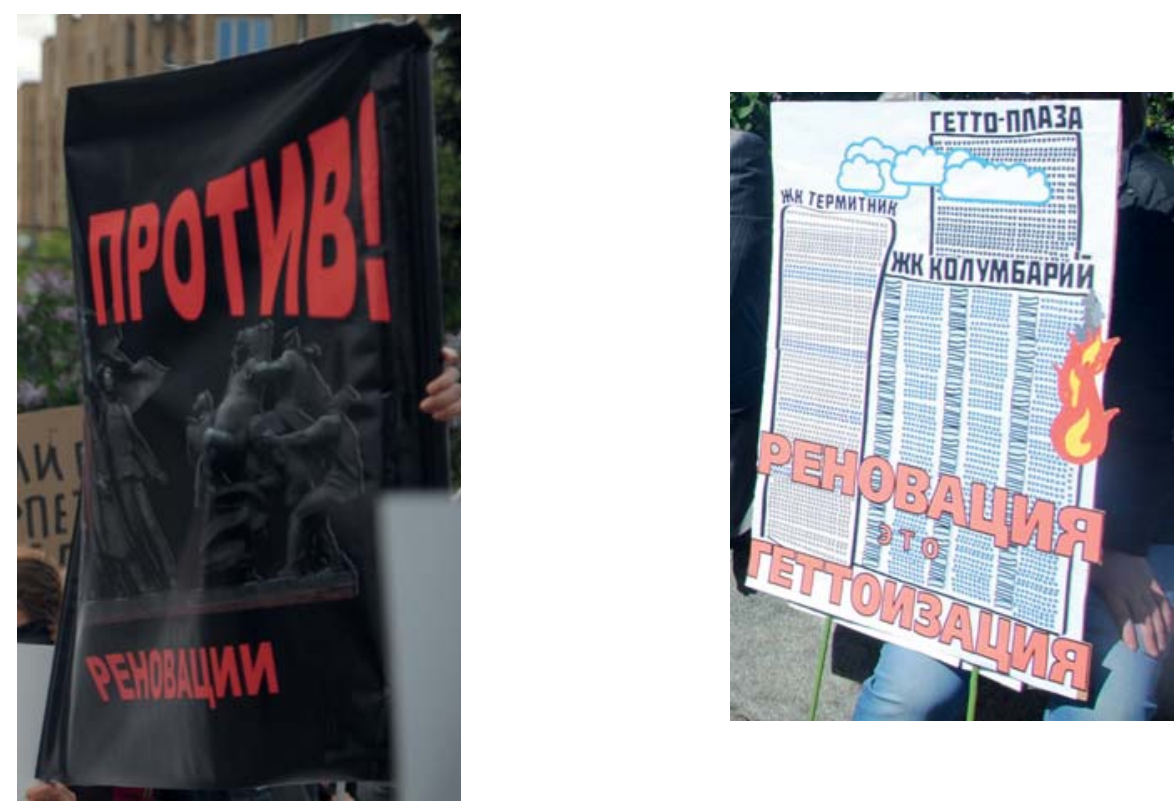

Figure 4. Signs waved during the protest of the protest of the 12th June 2017 in Moscow: "against renovation" (on the left); "renovation is ghettoization" (on the right). Inizan, UMR EVS

district, in the northeastern part of the central okrug of Moscow, associations for the protection of the constructivist architecture advocated for the conservation of a house menaced of demolition ${ }^{20}$. As explains Alexandra Selivanova, the director of the Avantgarde Museum, it could be refurbished and welcome inhabitants again. Nevertheless, for some of the inhabitants who are currently living there, demolition is the insurance that they will be rehoused in better conditions, and that is why they protested in favor of it.

\section{Conclusion}

Urbanization growth under the Soviet regime was an expression of the modernization of the territory from the social, technological and economical points of view. However, the urban process in the USSR and in the other countries of the Eastern bloc was also the

\footnotetext{
${ }^{20}$ On the Gavrikova street. Cf. http://www. the-village.ru/village/city/places/304161-rusakovka [20 March 2018].
}

expression of an ideological project, underlined by radical political turns in the architecture, a strict political control over the urban territory and over the production of the city and the allocation of dwellings. During those decades, the expression of the power over the urban population had been targeting the building of a new architecture representing a socialist way of life. Something new is occurring in post-Soviet Russia. One of the main public urban projects consists not in building, but in demolishing entire parts of the dwelling stock, mainly apartment blocks of the Khrushchev period. Demolition as an overall project seems to be a new governing tool. By announcing a program with an unprecedented sweep and keeping some aspects of its implementation imprecise, the government, while involving the citizens in a new way by organizing votes, puts citizens on hold. This contributes to stirring up new kinds of protests in Moscow. The program has just been announced, and the greatest part is still to be realized. Further 
studies have to be launched to offer details on these first analyses in Moscow, notably on the spatial aspects of the implementation of the program and its contestation.

Future studies should also investigate disparities and inequalities between Moscow and the other cities in Russia. The program has implied a modification of the 1993 law about the 'specific statute' of the Russian capital. What about the hundreds of other cities where the khrushchevki and, more broadly speaking, the question of 'Renovation' has no such place in the public debate? On the television channel Pervyi kana/21, a participant asked the President of the Russian Federation Vladimir Putin whether such a program will occur in other cities, to which he answered that it is possible in Moscow because the municipality has 'money', which is not the case of other Russian cities. Moscow is not only the fastest growing city, whereas the other urban areas in Russia are depopulating or shrinking (Cottineau 2016), but also the only city where there exists a program to answer to the deterioration of the khrushchevki. What will the khrushchevki in other cities become ${ }^{22}$, where municipalities and inhabitants raise the question of demolition but nothing is planned yet?

What lessons can be drawn out of this Russian case study? First let us come back to the word Renovation. It is worth comparing it briefly to the French situation, since the same word has been used there at the beginning of the twenty-first century in a broad program of 'Rénovation urbaine'23 planned between 2004 and 2020. In many cities in France, 250,000 dwellings have to be demolished, 250,000 should be built, and 400,000 revitalized. It includes also the restructuring of public spaces, of the public transportation offer, new social and cultural

21 On 15 June 2017.

22 Cf. for instance, in the case of Perm: http:// rifey.ru/news/perm/show_id_52939/12-04-2017-vpermi-poka-ne-planiruyut-massovyy-snos-hrushchevok [20 March 2018].

23 Programme National de Rénovation Urbaine https://www.anru.fr/fre/Programmes/ProgrammeNational-pour-la-Renovation-Urbaine [20 March 2018]. amenities, etc. The program concerns 4 millions of inhabitants located in 400 districts, mostly large prefabricated and social housing estates built during the fifties and the seventies of the 20th century. A major difference with the Russian situation is that the physical demolition of parts of cities in France is supposed to resolve social problems of urban segregation by bringing (back) social diversity (mixité) in these districts, in a word, demolition should help to "break ghettos" (Lelévrier 2010). The renovation is supposed to act as a "remedy to the social issue" (Bellanger et al. 2018) and solve social inequalities. From the institutional and architectural point of view, the renovation can be read as a "population policy" (Epstein 2014) that particularly targets certain social categories. Besides, its implementation, notably the rehousing process affects the social, economic, familial structure of the inhabitants (François 2014). In Russia, the social issue is almost absent of the aims of the program as they are formulated by the authorities: the officially aim is mainly to provide modern houses. However, khrushchevki, as housing buildings also determine social relations and positions as they are spatially structured and their demolition bring about social changes. Promotion of the program by the municipality already indicates that the new buildings replacing the khruschhevki are presented as the material and spatial frame and conditions to do "a step towards the future" 24 . Inquiries with urban planners could help to precise if the geographical structure of the program aims to target specific social categories. Moreover, like different works (Attwood 2010) analyzed the difference between the official propaganda for the brand new khrushchevki in the ninetenn fifties and sixties and the concrete conditions of living, the unequal access to new houses, the implementation of the current renovation could be further studied through inquiries with the rehoused inhabitants.

\footnotetext{
${ }^{24}$ Citation from a video of promotion published by the municipality https://www.youtube.com/channel/ UCywW9XIdSpE3HVmWxW1RYFw [1 March 2018].
} 
The second interesting point is the role of inhabitants, and the governance of demolition. The voting and the implementation of the renovation policy raise questions concerning the role of inhabitants. The 'participation', initially studied in the American context (Arnstein 1969) and used to read European renovation policies (Donzelot \& Epstein 2006) has often been questioned in the case of the rénovation urbaine in France. The importance of reports made for the settlers of this renovation (Kedadouche 2003; ANRU 2006) reveals that it became one of its key issues, even if a lot of studies showed that in reality, participation of inhabitants was extremely limited (Epstein 2015). In the Muscovite case, the involvement of the inhabitants in the process can hardly be qualified as 'participation' as it is discussed in the French case. Nevertheless, the unprecedented integration of inhabitant's opinions through the consultation, their mobilization for post-soviet housing legalization (especially general meetings of owners) showed that they strongly react and influence

\section{References}

ABRAmOVA E., 2015. The Bolotnaya Square: Urban design in Moscow between social activities and political protests. Widok. Teorie i pratyki kultury wizualnej, http://pismowidok.org/index.php/ one/article/view/272/554 [15 March 2018].

Aman A., 1992. Architecture and ideology in Eastern Europe during the Stalin era: An aspect of cold war history. Cambridge: MIT Press.

Amestor I., 2004. Les grands ensembles en Russie, de l'adoption d'un modèle à la désaffection [in :] F. Dufaux, A. Fourcaut, Le monde des grands ensembles, Paris: Créaphis, pp. 129-142.

AnDRusz G.D., 1984. Housing and urban development in the USSR, Albany: State University of New York Press.

ANRU, Comité d'Évaluation et de SuIVI, 2006. Note sur la participation des habitants.

Argenbright R., 2016. Moscow under construction: City building, place-based protest, and civil society. Lanham: Lexington Books. the setting of this yet dop-down policy. Studies of their reactions and mobilizations and their role in the implementation of the policy have to be further provided in order to enrich the understanding of the participation of habitants in urban policies, often focused on the European and American cases (Kirszbaum 2010; Bacqué \& Gauthier 2011). Social and political stakes of the role of the inhabitants in the process of urban renovation remain to explore in post-soviet urban studies (Golubchikov 2017).

\section{Acknowledgements}

This paper was completed in the LABEX IMU (ANR-10-LABX-0088) at the University of Lyon. It is a part of the Research Program "Habiter Ensemble la Ville de Demain".

Editors' note:

Unless otherwise stated, the sources of tables and figures are the authors', on the basis of their own research.

ARnSteIN S.R., 1969. A ladder of citizen participation. Journal of the American Institute of Planners, vol. 35, no. 4, pp. 216-224.

Attwood L., 2010. Gender and housing in Soviet Russia: Private life in a public space. Manchester: Manchester University Press.

Azarova K., 2007a. Appartements communautaires à Moscou: un territoire partagé. L'Homme et la société. vol. 165-166, no. 3, pp. 161-175.

AzArova K., 2007b. L'appartement communautaire: I'histoire cachée du logement soviétique. Paris: Éd. du Sextant.

Bacqué M.-H., Gauthier M., 2011. Participation, urbanisme et études urbaines: Quatre décennies de débats et d'expériences depuis 'A ladder of citizen participation' de S.R. Arnstein. Participations, vol. 1, no. 1, pp. 23-40.

Badyina A., GolubchiKov O., 2005. Gentrification in central Moscow - a market process or a deliberate policy? money, power and people in housing regeneration in ostozhenka. 
Geografiska Annaler: Series B, Human Geography, vol. 87, no. 2, pp. 113-129.

Bairoch P., Batou J., Chevre P., 1988. La population des villes européennes de 800 à 1850 . Genève: Droz.

Barjot D., Baudouï R., Voldman D., 1997. Les reconstructions en Europe, 1945-1949: [actes du colloque international, Caen, 20-22 février 1997]. Bruxelles: Éd. Complexe.

Bellanger E., Collet A., Desage F., Gilbert P., 2018. Rénovation urbaine. L'espace comme remède à la question sociale?. Métropolitiques. eu, https://www.metropolitiques.eu/Renovation-urbaine-L-espace-comme-remede-a-laquestion-sociale.html [15 March 2018].

Bierut B., 1951. Plan sześcioletni odbudowy Warszawy. Warszawa: Książka i Wiedza.

Carton de Grammont S., 2009. Faire un musée vivant : la production d'une autochtonie urbaine à Moscou, Histoire urbaine, no. 25, pp. 83-104.

Ciborowski A., 1969. Warszawa. O zniszczeniu i odbudowy miasta. Warszawa: Wydawnictwo Interpress.

CIEŚLA S., 2000. Globalizacja i metropolizacja. Niektóre aspekty badań polskiej przestrzeni, Studia Regionalne i Lokalne, vol. 4, no. 4, pp. 23-36.

Cottineau C., 2012. Un système intermédiaire. La trajectoire des villes russes entre dynamiques générales et histoires spécifiques. L'Espace géographique, vol. 41, no. 3, pp. 266-284.

Cottineau C., 2016. A multilevel portrait of shrinking urban Russia. Espace populations sociétés, no. 2015/3-2016/1, https://journals.openedition.org/eps/6123 [15 March 2018].

Coudroy de Lille L., 2011. Les héritages socialistes à l'épreuve des dynamiques urbaines à Varsovie: entre "banalisation " et patrimonialisation [in :] P. Gradvohl (ed.), L’Europe médiane au $X X^{\circ}$ siècle. Fractures, décompositions, recompositions, surcompositions, Prague: CEFRES, pp. 35-53.

Coudroy de Lille L., Guest M., 2010. Towards banalization? Trans-forming the legacies of the post-socialist city [in:] A. Kliems, M. Dmitrieva (eds.), The post-socialist city. Continuity and change in urban space and imagery, Berlin: Jovis, pp. 34-51.

CZEPCZYŃSKI M., 2010. Representations and images of 'recent history'. The transition of post- socialist landscape icons [in:] A. Kliems, M. Dmitrieva (eds.), The post-socialist city. Continuity and change in urban space and imagery, Berlin: Jovis, pp. 16-32.

DAuCÉ F., 2005. Les analyses de l'engagement associatif en Russie, Centre d'études et de recherches internationales Sciences Po, https:// www.sciencespo.fr/ceri/sites/sciencespo.fr.ceri/ files/qdr14.pdf [15 March 2018].

DeCREe N-497, 2017. Postanovlenie pravitel'stva Moskvy N-497-PP ot 1 avgusta O programme renovatsii zhilischchnogo fond $v$ gorode Moskve [Decree of the Government of Moscow N-497-PP of 1 August 2017 On the Programme of Renovation the housing stock in Moscow].

Deschepper J., 2017. Mémoires plurielles et patrimoines dissonants: I'héritage architectural soviétique dans la Russie poutinienne. Le Mouvement Social, vol. 260, no. 3, pp. 35-52.

Diefendorf J.M., 1989. Urban reconstruction in Europe after World War II. Urban Studies, vol. 26, no. 1, pp. 128-143.

Donzelo T.J., Epstein R., 2006. Démocratie et participation: l'exemple de la rénovation urbaine. Esprit, no. 7, pp. 5-34.

Engels F., 1976 [1873]. La question du logement, Paris: Editions sociales.

EPSTEIN R., 2014. (Dé)politisation d'une politique de peuplement: la rénovation urbaine du XIXe au XXle siècle [in :] F. Desage., C. Morel-Journel, V. Sala Pala (eds.), Le peuplement comme politiques. Rennes: Presses universitaires de Rennes, pp. 329-354.

EPSTEIN R., 2013. La rénovation urbaine: démolition-reconstruction de l'Etat. Paris: Presse de Sciences Po, coll. 'Sciences Po Gouvernance'.

François C., 2014. Disperser les ménages: Groupes résidentiels et familiaux à l'épreuve de la démolition d'un grand ensemble. Actes de la recherche en sciences sociales, vol. 204, no. 4, pp. 102.

GolUBCHIKOV O., 2017. The post-socialist city: Insights from the spaces of radical societal change [in]: A Research Agenda for Cities, Edward Elgar Publishing, pp. 266-280.

Gunko M., Bogacheva P., Medvedev A., KashNITSKY I., 2018. Path-dependent development of mass housing in Moscow, Russia [in:] D.B. Hess, T. Tammarut., M. Van Ham M. (eds.), Housing Estates in Europe, Cham: Springer International Publishing, pp. 289-311. 
Hamilton F.E.I., Andrews K.D., PichlerMilanović N., 2005. Transformation of cities in Central and Eastern Europe. Towards globalization. New York: United Nations University Press.

HarrIS C.D., 1970. Cities of the Soviet Union: Studies in their functions, size, density, and growth. Chicago: Rand McNally.

IOSA I., 2006. L'héritage urbain de Ceausescu: fardeau ou saut en avant? Le centre civique de Bucarest. Paris: L'Harmattan.

JANKOWSKI S., 1990. Warsaw: Destruction, secret town planning, 1939-44, and postwar reconstruction [in:] J.M. Diefendorf (ed.), Rebuilding Europe's bombed cities, London: Palgrave Macmillan UK, pp. 77-93.

KaLININA N., 1992. Housing and housing policy in the USSR [in:] B. Turner, J. Hegedüs, I. Tosics (eds.), The reform of housing in Eastern Europe and the Soviet Union, London: New York Routledge, pp. 245-275.

Kalyukin A., Borén T., Byerley A., 2015. The second generation of post-socialist change: Gorky Park and public space in Moscow. Urban Geography, vol. 36, no. 5, pp. 674-695.

Kedadouche Z., 2003. Participation des habitants dans les opérations de renouvellement urbain. Rapport à Jean-Louis Borloo, http://www. crpve91.fr/Habitat,_Cadre_de_vie/Participation_des_habitants/Textes_de_reference/ pdf/2003_04_Rapport_sur_la_participation_ des_habitants_dans_les_operations_de_ renouvellement_urbain.pdf [15 March 2018].

KirszBAum T., 2009. La rénovation urbaine estelle une politique de justice sociale? Synthèse du Petit déjeuner du pôle de ressources du 8 octobre 2009, http://www.poleressources 95.org/publications/dossiers_syntheses_detail-130-la-renovation-urbaine-estelle-une-politique-de-justice-sociale--.html [15 March 2018].

Kolossov V., O'Loughuin J., 2004. Comment Moscou se transforme en ville géante capitaliste. Revue internationale des sciences sociales, no. 181, pp. 463-477.

Kolossov V., Vendina O., O'Loughlin J., 2002. Moscow as an emergent world city: International links, business developments, and the entrepreneurial city. Eurasian Geography and Economics, vol. 23, no. 3, pp. 170-196.
Kopp A., 1975. Changer la vie, changer la ville. De la vie nouvelle aux problèmes urbains. URSS. 1917-1932. Paris: Union Générale des Editions.

Kopp A., 1985. L'architecture de la période stalinienne. Grenoble: Presses Universitaires de Grenoble.

Krakovsky R., 2005. Politiques symboliques: à l'est, du nouveau. La Nouvelle Alternative, vol. 20, no. 66-67, pp. 203.

KUSIAK J., 2014. Porzadki chaosu. 'Chaos' jako pojęcie i zjawisko empiryczne w Warszawie po 1989 r. Studia Regionalne i Lokalne, vol. 55, no. 1, pp. 28-50.

LeléVRIeR C., 2010. La mixité dans la rénovation urbaine: dispersion ou re-concentration? Espaces et sociétés, no. 140-141, pp. 59-74.

LEŚNIAKOWSKA M., 2009. Varsovie, ville palimpseste [in:] E. Berard, C. Jaquand (eds.), Architectures au-delà du mur: Berlin, Varsovie, Moscou, 1989-2009, Paris: Picard, pp. 241-249.

LOWE K., 2013. L'Europe barbare: 1945-1950. Paris: Perrin

Medvedkov Y., Medvedkov O., 2007. Upscale housing in post-Soviet Moscow and its environs [in:] K. Stalinov (ed.), The post-socialist city. Urban Form and Space Transformations in Central and Eastern Europe after Socialism, Dordrecht: Springer, pp. 245-265.

MisHINA V., Snosu im ne budet [They won't be demolished]. [On-line] 22 September 2017, Kommersant, https://www.kommersant.ru/ doc/3420440 [15 March 2018].

PerRY F., 2016. Moscow demolishes "illegal" shops around its metro stations - in picture. [Online] 9 February 2016, https://www.theguardian.com/cities/gallery/2016/feb/09/moscowdemolishes-illegal-shops-kiosks-metro-stations [20 March 2018].

RICHARD H., 2008. Du troc au marché: le marché immobilier à Moscou. Autrepart, vol. 48, no. 4, pp. 87-99.

Richard H., 2014. Comment les Russes sont-ils devenus (co)propriétaires?. Lyon-2, [PhD Thesis], https://tel.archives-ouvertes.fr/tel-01180340 [15 March 2018].

Ter Minassian T. (ed.), 2013. Patrimoine \& architecture dans les États post-soviétiques: contributions rassemblées au cours de deux journées d'études organisées en 2011 par l'Observatoire 
des États Post-Soviétiques de l'INALCO, Rennes: Presses Universitaires de Rennes.

Tung A.M., 2001. Preserving the world's great cities. The destruction and renewal of the historic metropolis. New-York: Three Rivers Press.

Vendina O., 2014. Sotsialnyi atlas Moskvy. Proekt Russia, https://issuu.com/mosurbanforum/ docs/ [15 March 2018].
Voisin-Bormuth C., 2013. How to build the public spaces of a democracy? The design of new public spaces in the city centre of Dresden after reunification [in:] A. Madanipour., S. Knierbein, A. Degro (eds.), Public space and the challenges of urban transformation in Europe, New York: Routledge, pp. 78-87. 